\title{
УДК 94/32.019.52
}

http://doi.org/10.17721/2521-1706.2016.02.111-117

Ірина Зубаренко,

кандидат історичних наук,

Одеський національний університет імені I. І. Мечникова

\section{АМЕРИКАНСЬКИЙ ФАКТОР В «АРАБСЬКІЙ ВЕСНІ» КРАЇН МАГРИБУ: ІЛЛЮЗІЇ ТА РЕАЛІЇ}

\begin{abstract}
Анотація. Статтю присвячено дослідженню впливу американського фактору на події револючійного характеру у країнах Магрибу. У якості реакиії з боку Сполучених Штатів Америки на події «Арабської весни» у регіоні приведено низку цитат з заяв головних політичних сил, громадських організацій краӥни та провідних науковців, експертів щзо представляють різноманітні аналітичні центри, наукові та освітні установи. Водночас, автор звертає увагу на внутрішньополітичні чинники, що спровокували спалах народних невдоволень і призвели до подальших наслідків.

У статті, зокрема, розглянуто ключові події «Арабської весни» у краӥнах Магрибу, перебіг револючій в Тунісі, Марокко, Алюсиі, Лівї̈ та їх суспільно-політичні і економічні наслідки, зокрема, приходу до влади проісламістьських партій та ісламізацію суспільнополітичного життя після револючій та повалення старих, авторитарних режимів. Також в статті, на підставі тверджень провідних світових аналітиків, висловлюється версія, щзо революиії в країнах Магрибу та повалення старих авторитарних режимів мало $i$ фінансовий підтекст. Проаналізовано основні підсумки «Арабської весни» у краӥнах Магрибу та ї̈ досягнення і досить неоднозначні та суперечливі наслідки.
\end{abstract}

Ключові слова: США, Арабська весна, револючія, політика.

Спроба об’єктивно розглянути ставлення США до революційних подій в країнах Магрибу натикається на низку фактів спекулятивно-ажіотажного характеру, що їх було використано зацікавленими сторонами в бажанні нав'язати своє бачення тогочасних реалій. Однак, передусім аналіз внутрішньополітичних передумов і причин «Арабської весни» допомагає неупереджено визначити ступінь впливу зовнішніх чинників, у тому разі і американського фактору, на хвилю політичних протестів у регіоні.

Як відомо, початок так званій Арабській весні було покладено 17 грудня 2010 p. у Тунісі. Основною причиною невдоволення молодих тунісців був великий розмах корупції у вищих ешелонах влади. Потягом 24-річного правління президент Зінель-Абідіна Бен Алі разом $з$ дружиною Лейлою Трабелсі, уродженкою багатого клану, підпорядкували своєму впливу всі ключові галузі економіки. Водночас безробіття в країні набирало усе більших обертів. Особливо гостро ця проблема торкнулася освіченої молоді віком 21-25 років. У 2010 р. випускники ВНЗ склали $60 \%$ від загального числа безробітних тунісців [3, с. 63]. Ці молоді люди і стали головною рушійною силою революції. Окрім того, для збереження авторитарності свого режиму президент Зінель-Абідін Бен Алі обмежив діяльність опозиційно налаштованих політиків. Де-юре політичний плюралізм не було скасовано, проте де-факто лише одна партія «Демократичне конституційне об'єднання» залишалась при владі з 1988 року.

На додаток до цих факторів, які певним чином спровокували «Арабську весну» у Тунісі, існує версія про те, що зацікавленість влади у розвитку 
ісламського банкінгу стала майже головним каменем спотиканням у відносинах між президентом Зінель-Абідін Бен Алі з західним світом, у тому разі і з США.

26 травня 2010 р. зять президента Захер аль-Матері відкрив банк «Зейтуна», який став першим ісламським банком в регіоні Магрибу. Цей банк мав започаткувати нову урядову програму по перетворенню Тунісу у полюс банківського обслуговування та регіональний фінансовий центр Північної Африки. 19 жовтня 2010 р. урядом Тунісу було засновано два грандіозних проекти Ісламський інвестиційний банк (Gulf Finance House) і перший у регіоні офшорний фінансовий центр (Tunis Financial Harbour). Цей центр вартістю у 3 млрд. амер. дол. мав стати структурною частиною проекту з розвитку прибережної зони Тунісу i забезпечити 16 тис. робочих місць.

Слід зауважити, що ісламські банки згідно Шаріату не мають права стягувати відсотки 3 вкладників. I саме цей факт став своєрідною зачіпкою для того, щоб перекласти провину за спалах політичного перевороту у Тунісі на впливові політичні та фінансові кола США. У низці досліджень фігурувала інформація про те, що відома династія Ротшльдів, побоюючись ослаблення свого фінансового впливу в Північній Африці, взялася за підготовку кадрів з середовища освіченої арабської молоді для проведення революцій. У статті «Сгипет і Туніс: плутократія виграла» американський політолог К. Болтон пише: «Національний фонд на підтримку демократії (National Endowment for Democracy) разом 3 Д. Соросом (одним із членів правління і провідним ідеологом Міжнародної кризової групи, підтримуваної Ротшильдами) працювали в тандемі, націлюючись на одні і ті самі режими і використовуючи однакові методи. Національний фонд на підтримку демократії протягом 2007-2009 pp. регулярно надавав гранти для навчання молодих активістів у Тунісі та інших державах Північної Африки. Лише у 2008 р. Туніський Форум «аль-Джахід» отримав 57000 амер. дол. на просування демократичних цінностей; Науково-освітній центр Мохаммеда Алі - 37800 амер. доларів; Арабський інститут «Civitas» - 43000 амер. дол. на підвищення кваліфікації викладачів; Центр міжнародного приватного підприємництва 163205 амер. дол. на впровадження доктрин приватного підприємництва серед туніських бізнесменів» [9]. Таким чином, на думку К. Болтона, Ротшильди та їх партнери інвестували чималі суми на підготовку кадрів, які згодом допоможуть у поваленні арабських диктаторів з багаторічною історією правління, переслідуючи головну мету - протистояти бурхливому розвитку економікам країн Північної Африки. Усунення Зін аль-Абідіна Бен Алі з посади президента практично звело на нівець його зусилля перетворити Туніс у регіональний фінансовий центр. Західні банкіри були зацікавлені у тому, щоб північноафриканські жителі брали в борг у їх банків замість того, щоб займати у ісламських банків без сплати жодних відсотків.

Офіційний Вашингтон також схвалив прагнення молодих тунісців до демократичних перетворень. 15 січня 2011 р. на сайті BBC News була опублікована стаття «Реакція на кризу в Тунісі в цитатах», в якій висвітлювалися оцінки і думки ряду глав держав і організацій щодо революції в Тунісі. Зокрема президент США Барак Обама заявив: «Я засуджував i надалі засуджуватиму застосування насильства по відношенню до громадян Тунісу, які мирними способами висловлюють свої бажання, а також я у захваті від мужності туніського народу. Сполучені Штати від імені широкої міжнародної громадськості підтримують 
сміливу і рішучу боротьбу тунісців за свої права. Я не сумніваюся, що майбутнє Тунісу буде значно яскравіше, якщо воно буде сформовано голосом народу» [16].

Головною правлячою силою після виборів у Тунісі у жовтні 2011 р. став рух помірних ісламістів «Ан-Нагда», ідейно близький єгипетським «Братам мусульманам». Ліберали, які опинилися в меншості почали звинувачувати «АнНагду» в планах щодо ісламізації держави. I дійсно, відразу після повалення режиму президента Зінель-Абідіна Бен Алі в самій світській країні Арабського світу стали активно діяти угруповання консервативних ісламістів-салафітів. У Тунісі в вільному обігу виявилося чимало зброї з сусідньої Лівії, що потенційно посилювало небезпеку здійснення терактів. Парадоксальним $є$ той факт, що у своєму прагненні дарувати громадянам Тунісу демократичні свободи і зробити країну відкритою для зовнішнього світу, президент Зіналь-Абідін Бен Алі отримав зворотну реакцію. Також очевидно, що прагнення туніської інтелігенції до встановлення демократії прозахідного зразку набуло ілюзорності в контексті ісламізації країни, керованої новим урядом.

Туніський антиурядовий переворот спровокував у Арабському Світі ефект доміно, вслід за ним спалахнули революції, що призвели у низці країн регіону до повалення багаторічних правлячих режимів.

Під тиском демонстрацій, які пройшли у Алжирі наприкінці січня та в лютому 2011 року, президент Абдель Азіз Бутефліка скасував надзвичайний стан, який діяв в країні останні 19 років. Це означало, що повноваження збройних сил АНДР втручатися у питання внутрішньої безпеки будуть істотно обмежені. Президент Абдель Азіз Бутефліка гарантував, що в основі нової державної політики буде закладена антикорупційна кампанія, спрямована на захист національної економіки; при цьому він заявив, що i надалі продовжуватиме боротьбу 3 діяльністю терористичних організацій ісламістського толку [6].

Акти самоспалення та масові протести торкнулися і єдиної арабської Манрибу, Королівства Марокко. 20 лютого 2011 р. тисячі демонстрантів вийшли на вулиці Рабату і Касабланки з вимогами внести радикальні зміни до конституції країни. Мирні демонстрації переросли у зіткнення і заворушення, в ході яких загинуло 6 осіб і понад 100 було поранено. У столиці 10-тисячний натовп, що складається переважно 3 ісламістів i «лівих», наполягав на поваленні режиму короля Мохаммеда VI, який перебував на престолі з 1999 року. Роберт М. Холлі, виконавчий директор Американо-марокканського центру політичних досліджень у Вашингтоні прокоментував цю ситуацію наступним чином: «Марокко вже не та країна, що була 10-15 років тому. Люди хочуть зміни влади, але їм просто потрібно почекати пару років до наступних виборів і зробити це коректніше» [10].

Слід вказати на те, що за період правління короля Мохаммеда VI, Марокко набуло більш м'якої форми авторитаризму у порівнянні з режимом його батька, короля Хасана II. Цивільні права жителів, особливо жінок, було розширено, помітно покращилася ситуація у сфері дотримання прав людини, країна досягла певних успіхів в соціально-економічному розвитку. Однак мала місце і критика в зв'язку 3 масовою корупцією, бідністю, обмеженнями свободи преси, неписьменністю і іншими проблемами.

26 листопада 2011 р. у Марокко було проведено парламентські вибори, на яких перемогла ісламістська Партія справедливості i розвитку на чолі 3 Абделілахом Бенкіраном, а вже наступного дня країну відвідала американської 
делегації високого рівня. У заяві одного з членів цієї делегації, помічника Держсекретаря США з політичних справ Вільяма Бернса йдеться про те, що «Марокко є єдиною вдалою моделлю 3 проведення реформ і демократизації у Північній Африці» [15].

Держсекретар США Гіларі Клінтон під час цього візиту похвалила реформи короля Мохаммеда VI підкресливши, що саме завдяки їм, Марокко стало зразком для усіх країн регіону в питаннях просування демократії. За підсумками візиту сторони заявили про свій намір і надалі розвивати дружні відносини і плодотворне співробітництво. Держсекретар США підтримала пропозиції офіційного Рабату 3 врегулювання проблеми Західної Сахари шляхом надання їй статусу автономії у складі Королівства Марокко. Гіларі Клінтон класифікувала ці пропозиції як серйозні, реалістичні i такі, що заслуговують на довіру з боку міжнародної спільноти [21].

Значно гострішим проявом революційних настроїв стали події в Лівії. 17 лютого 2011 р. в ході вуличних протестів у містах Бенгазі, Бевіда, Зентан, Ружбан і Дерна було вбито 19 осіб [14]. Водночас у Тріполі пройшов мітинг прихильників М. Каддафі. У західних ЗМІ з'явилася інформація про те, що під час заворушень у містах Кіренаїки 18-20 лютого 2011 р. лівійська влада дала наказ розстріляти демонстрацію протестантів 3 кулеметів; загинуло близько 200 осіб, близько 800 отримали поранення [18]. Однак на офіційному рівні ці відомості не було підтверджено. На думку провідного спеціаліста Інституту стратегічних досліджень при Президенті України О. Воловича «лівійські заворушення стали вдалим моментом для активації традиційної політики Сполучених Штатів» «демонстрації мускулів» [2].

25 лютого 2011 р. Білий Дім призупинив дипломатичні відносини 3 Лівією і заявив про свій намір ввести проти неї санкції. Також Б. Обама видав указ заморозити активи М. Каддафі, його дітей, і представників лівійського уряду. Прессекретар Б. Обами Д. Карні констатував, що легітимність влади М. Каддафі «дорівнює нулю». На думку Д. Карні, «після того, як лівійський лідер наказав жорстоко придушувати виступи своїх супротивників, що призвело до безлічі жертв, він остаточно втратив довіру народу» [22].

4 березня 2011 р. Б. Обама настійно закликав М. Каддафі піти у відставку. Голова Білого Дому висловив ідею про те, що «якщо під визначенням лідера нації розуміється лише використання політичної сили з метою насильства над людьми, то в цьому випадку йому необхідно негайно покинути свій пост». Також президент США стверджував, що «необхідно створити безпольотну зону над Лівією для захисту мирних громадян від урядових літаків, однак будь-яку ініціативу він особисто буде узгоджувати на міжнародному рівні» [20].

Слід зазначити, що у Лівії на момент спалаху громадянської війни було набагато менше у порівнянні 3 сусідніми державами проблем соціальноекономічного характеру; вона займала 53 місце в Індексі розвитку людського потенціалу, рівень грамотності досягав 88,9\% [1, с. 157]. М. Каддафі був ініціатором надання лівійцям безкоштовної освіти, медичних послуг і необхідної фінансової допомоги для придбання житла. Завдяки побудованій рукотворної річці, три чверті населення Лівії було забезпечено питною водою. Середня зарплата лівійців складала 1050 амер. доларів [8]. Однак у Лівії, як і в інших арабських державах, не втрачала актуальності проблема безробіття, і був досить високий 
рівень корупції. У доповіді за 2010 р. неурядова організація «Дім Свободи» (Freedom House) оцінила свободу преси і можливість реалізації політичних прав в Лівії, поставивши рейтинг 7, що означає вкрай низький рівень [13]. При М. Каддафі в шкільній програмі не передбачалось вивчення англійської та французької мов, а розмова 3 іноземцями на політичні теми каралась трьома роками позбавлення волі [7]. Дисидентські руху у Лівії перебували під забороною, а за заснування політичних партій передбачалась страта.

Інтервенція сил НАТО у Лівії розпочалася 19 березня і офіційно завершилася 31 жовтня 2011 року. Сполучені Штати взяли на себе левову частку в проведенні низки операцій. За повідомленням Міністерства оборони США, американські війська виконали $80 \%$ усіх заправок у повітрі, $75 \%$ від загального часу патрулювання повітряного простору i 100\% місій зі знищення засобів радіоелектронної боротьби. Окрім того 29 березня 2011 р. американські бойові літаки атакували три кораблі ВМС Лівії, які, як розповів представник міністерства оборони США, відкрили вогонь по цивільним судам в порту міста Місурата [12].

П. Ставракіс, професор політології при Національному університеті оборони США, вважає, що «при такій кількості задіяних сил з боку Заходу і при певному балансі захист населення Лівії не міг бути безпосередньою метою цієї операції. Він висловив наступне припущення: «Я впевнений, що існує якийсь політичний підтекст, безпосередньо пов'язаний з поваленням режиму М. Каддафі» [4].

I як у випадку з Тунісом, зацікавлені сторони почали висловлювати версію про те, що саме фінансове питання стало на заваді порозуміння у американськолівійських відносинах. Станом на 2011 р. запаси нафти у Лівії становили понад 36 млрд. барелів, загальна вартість усіх розвіданих нафтових запасів - близько 3,8 трлн. амер. доларів. Опираючись на значні доходи від видобутку нафти (50 млрд. амер. дол. на рік), Лівія стала володаркою серйозних фінансових капіталів. Близько 200 млрд. амер. дол. було розміщено на лівійських рахунках у західних банках. Беручи до уваги цей факт, є ймовірність того, що причиною рішучого настрою Франції, Великобританії і США щодо повалення режиму М. Каддафі могли послужити плани лівійського лідера по переходу в розрахунках за нафту із західними партнерами 3 долара i євро на нову грошову одиницю золотий динар. Для втілення цієї ідеї в життя М. Каддафі планував залучити інші африканські країни.

У газеті «Аш-Шарк аль-Аусат» було надруковано звіт про секретні переговори між американськими і лівійськими посадовими особами. Згідно 3 документом, делегація США висловила готовність знайти для М. Каддафі відповідне політичний притулок в країні, готової прийняти його на своїй території. Відзначається, що ці переговори пройшли на початку квітня 2011 p. на території Тунісу, i представником від Лівії на них був Башир Салех, директор Канцелярії Муаммара Каддафі. У свою чергу, М. Каддафі поклявся «битися до останньої краплі крові» [5].

20 жовтня 2011 р. загони повстанців захопили штурмом місто Сирт, і після взяття в полон вбили М. Каддафі, його сина Муттазіма і Міністра оборони Лівії, бригадного генерала Абу Бакра Юніса Джабера.

Президент США Б. Обама відзначив, що загибель лівійського лідера «повинна послужити попередженням іншим диктаторам». Окрім того, він сказав, що настав 
«важливий день для Лівії, яка нарешті може почати свій шлях до всеосяжної демократії, а Сполучені Штати будуть підтримувати її на цьому шляху» [17].

Коли, майже рік по тому, 12 вересня 2012 р. нападу піддалося Консульство США в місті Бенгазі, багато хто угледів в цьому акт помсти. У наслідок обстрілу будівлі місії з гранатометів виникла пожежа. Посол США у Лівії К. Стівенс, який перебував на той момент у приміщенні, помер, отруївшись отруйними парами продуктів горіння.

Держсекретар США Г. Клінтон дивувалася: «Як таке могло статись у країні, яку ми допомогли звільнити, i в місті, який ми допомогли врятувати від руйнування?» Напад, за іiі словами, скоїла «невелика група дикунів» [11]. Президент Б. Обама, засудивши напад на американське консульство у Бенгазі, повідомив, що його адміністрація розслідує обставини спільно з лівійцями. «Будьте впевнені, правосуддя звершиться», - заявив він в телевізійному зверненні до народу [19].

Події «Арабської весни» у країнах Магрибу попри те, що вони здебільшого базувались невдоволенні народом правлячим режимом, і в цілому розгорталися за схожим сценарієм, мали різні наслідки. Якщо демонстрації у Алжирі завершились скасуванням надзвичайного стану, у Марокко внесенням змін до конституції, то у Тунісі вони переросли у революцію, що призвела до зміни влади. Найбільш радикальним проявом «Арабської весни» стали події у Лівії, які спровокували громадянську війну і загибель голови країни. 3 усуненням старих лідерів у регіоні утворився вакуум безпеки, а накопичені соціально-економічні проблеми лише посилились. Нові уряди виявились неспроможними виробити власну поведінкову стратегію, у тому разі і у відносинах з США. Повна розбалансованість у політиці зробила регіон слабким і вразливим на шляху до розбудови демократії.

\section{Література}

1. Доклад о развитии человека 2010. Программы развития Организации Объединенных Наций (ПРООН). - М.: Весь Мир, 2010. - 244 с.

2. Волович О. О. Ливия в огне: мятеж или революция? // Институт Ближнего Востока. [Електронний ресурc]. - Режим доступу: http://www.iimes.ru/rus/stat/2011/10-03-11d.htm.

3. Кашина А. А. Стратегия Туниса в области образования // Ближний Восток и современность. - 2010. - Вып. 42. - С. 60-68.

4. Купчинецкая В., Тихоненко И. Военная операция в Ливии: стратегия и тактика западной коалиции, 21.03.2011 // Голос Америки. [Електронний ресурс]. - Режим доступу: http://www.golosameriki.ru/content/libya-coalition-experts-2011-03-21-118.

5. Сауфа аль-Казафи имма мушарака милушуфитч имма масыр гитлир - аль-мутмарида альуазир аль-хариждия аль-либий, 30.04.2011 // Аш-Шарк аль-Аусат. [Електронний ресурс]. - Режим доступу: http://www.aawsat.net/2011/04/article55246671.

6. Algeria: meeting Saturday of the opposition after the liberalization measures, 04.02.2011 // Ennahar online. [Electronic resource]. - URL: http://www.ennaharonline.com/en/news.

7.A new flag flies in the east // The Economist, February 24, 2011. [Electronic resource]. - URL: http://www.economist.com/blogs/newsbook/2011/02/libya_fragments.

8. Azad S. Gaddafi and the media // Daily News, October 22, 2011 - on: Bolton K.R. Egypt and Tunisia: Plutocracy Won, June 28, 2011 // Foreign Policy Journal. [Electronic resource]. - URL: http://www.foreignpolicyjournal.com/2011/06/28/egypt.

9. Champion M. Morocco Joins in, Defying Predictions, February 21, $2011 / /$ The Wall Street Journal. [Electronic resource]. - URL: http://online.wsj.com/article.

10. Clinton: «How could this happen in a country we helped liberate?», September 12, 2012 // The Guardian. [Electronic resource]. - URL: http://www.gardian.co.uk/world/middle-east. 
11. DOD News Briefing with Vice Adm. Gortney from the Pentagon on Libya Operation Odyssey Dawn, March 28, 2011 // U.S. Department of Defense. [Electronic resource]. - URL: $\mathrm{http}: / /$ www.defense.gov/transcripts/transcript.aspx?transcriptid=4803.

12. Hassan S. Bahrain activists in 'Day of Rage', February 14, 2011 // Aljazeera. [Electronic resource]. - URL: http://www.aljazeera.com/news/middleeast/2011/02/2011214925802473.

13. Historical timeline // Kingdom of Morocco, Ministry of foreign affairs and cooperation. [Electronic resource]. - URL: http://www.diplomatie.ma/en/Accueil.aspx.

14. Hubbard B. 3 Arrested in Plot to Bomb Egyptian Cities and Embassy, May 11, 2013 // The New Your Times. [Electronic resource]. - URL: http://www.nytimes.com/2013/05/12/world.

15. In quotes: Reaction to Tunisian crisis, January 15, 2011 //BBC News Africa. [Electronic resource]. -

URL: htpp://www.bbc.co.uk/news/world-afrika.

16. Libya's Col Gaddafi killed in crossfire, says NTC, October 21, 2011 // BBC News Africa. [Electronic resource]. - URL: http://www.bbc.co.uk/news/world-africa-15397812.

17. Meo N. Libya protests: 140 'massacred' as Gaddafi sends in snipers to crush dissent, February 20, $2011 / /$ The Telegraph. [Electronic resource]. - URL: http://www.telegraph.co.uk.

18. Obama: attacks 'outrageous and shocking', September 12, 2012 // The Guardian. [Electronic resource]. - URL: http://www.gardian.co.uk/world/middle-east-live.

19. Obama calls on Gaddafi to leave, March 4, 2011 // IANS India Private Limited. [Electronic resource]. - URL: http://in.news.yahoo.com/obama-calls-gaddafi-leave.

20. Secretary Clinton's Interview with Samira Sitail in Morocco, February 27, 2012 // IIP Diigital U.S. Department of State. [Electronic resource]. - URL: http://iipdigital.usembassy.gov/st/english/texttrans/2012/02.

21. Winter M. U.S. imposing sanctions on Libya, shuttering embassy, February 25, 2011 // USA Today. [Electronic resource]. - URL: http://content.usatoday.com/communities.

Надійшла до редколегії 13.07.2016

Iryna Zubarenko, $\mathrm{PhD}$ in History, Associate Professor, Odesa National I. I. Mechnikov University, Ukraine.

\section{AMERICAN FACTOR IN «THE ARAB SPRING" OF MAGHREB COUNTIES: ILLUSIONS AND REALITIES}

Abstract. This paper intends analyze of the American influence on the revolutions in the Maghreb countries. To illustrate the American response to these events we cited declarations of the prominent political actors and researchers. At the same time, the author draws attention to the domestic issues that excited popular discontent and resulted in mostly negative repercussions.

The key events of the "Arab Spring" in the Maghreb countries, so to say, revolutions in Tunisia, Morocco, Algeria, Libya are examined. We also revealed social, political and economic consequences of these events, in particular of the rise to power of the pro-islamic parties, the "Islamization' of the social and political life which has begun after the overthrow of the authoritative governments. We also espouse the view of the internationally known analysts that revolutions in the Maghreb countries as well as the overthrow of the authoritative governments had an economic motive. Here we should mention clashes in financial relations with European countries and the USA, that of the Tunisian government's effort to establish a very own, Islamic investment bank what conflicted with Western financial and economic interests. Likewise, Europe and the USA were discontent with the plans of Libya as one of the biggest oil exporter, to switch from the dollar and euro to national currency, golden dinar, in petroleum accounting.

The ambiguous consequences of the "Arab spring" in the Maghreb countries are analyzed. In case of Morocco, the "Arab spring" had mostly positive consequences as the constitutional reforms and the cancellation of the state of emergence. However, in case of Libya, the revolution resulted in a civil war, and now the country is still very far from a political stability.

Keywords: the USA, the Arab Spring, revolution, politics. 